\title{
EHMTI-0331. Q-No: a questionnaire to predict nocebo in outpatients seeking neurological consultation
}

\author{
C Deligianni*, DD Mitsikostas \\ From 4th European Headache and Migraine Trust International Congress: EHMTIC 2014 \\ Copenhagen, Denmark. 18-21 September 2014
}

\section{Background and aim}

Nocebo affects significantly adherence and treatment outcome and varies considerably among neurological conditions. We aimed to evaluate a questionnaire to predict nocebo in outpatients seeking neurological consultation.

\section{Methods}

A four-item (rating range 0-20) self-fulfilled questionnaire (Q-No) was given in outpatients seeking neurological consultation at the Athens Naval Hospital. A blind to Q-No scoring neurologist rated outpatients as nocebo or no-nocebo after follow-up of $>6$ months.

\section{Results}

338 (71.6\% females) patients with mean age $46.9( \pm 13.8)$ years fulfilled the Q-No and the mean total score was 13.2 $( \pm 3.7)$. The Crombach's alpha coefficient was 0.627 . Neurologist suggested 80 patients $(23.7 \%)$ as nocebo and 258 as no-nocebo (mean Q-No score $=12.4$ 95\% CI: [12.0-12.9] and 15.8, 95\%CI: [15.1-16.6], respectively). By using a cut-off at score 16 the Q-No predicts nocebo with $82.6 \%$ specificity and $61.3 \%$ sensitivity.

\section{Conclusions}

Q-No may serve as a useful tool to predict nocebo in outpatients seeking neurological consultation.

No conflict of interest.

Published: 18 September 2014

Neurological Department, Athens Naval Hospital, Athens, Greece
doi:10.1186/1129-2377-15-S1-D14

Cite this article as: Deligianni and Mitsikostas: EHMTI-0331. Q-No: a questionnaire to predict nocebo in outpatients seeking neurological consultation. The Journal of Headache and Pain 2014 15(Suppl 1):D14.

\section{SpringerOpen ${ }^{\odot}$}

(C) 2014 Deligianni and Mitsikostas; licensee Springer. This is an Open Access article distributed under the terms of the Creative Commons Attribution License (http://creativecommons.org/licenses/by/2.0), which permits unrestricted use, distribution, and reproduction in any medium, provided the original work is properly cited.
Submit your manuscript to a SpringerOpen ${ }^{\circ}$ journal and benefit from:

- Convenient online submission

- Rigorous peer review

- Immediate publication on acceptance

- Open access: articles freely available online

- High visibility within the field

Retaining the copyright to your article

Submit your next manuscript at $>$ springeropen.com 